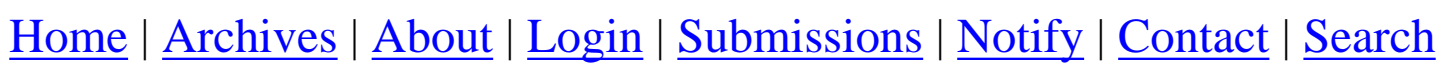

Copyright @ 2000 by The Resilience Alliance

The following is the established format for referencing this article:

Peterson, G., S. Cunningham, L. Deutsch, J. Erickson, A. Quinlan, E. Raez-Luna, R. Tinch, M. Troell, P. Woodbury, and S. Zens. 2000. The risks and benefits of genetically modified crops: a multidisciplinary perspective. Conservation Ecology 4(1): 13. [online] URL: http://www.consecol.org/ vol4/iss1/art13/

A version of this article in which text, figures, tables, and appendices are separate files may be found by following this link.

Young Scholar Dialogue, part of Special Feature on Genetically Modified Organisms

The Risks and Benefits of Genetically Modified Crops: A Multidisciplinary Perspective

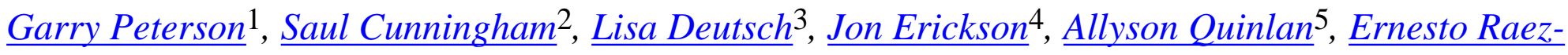
$\underline{\text { Luna }}^{6}, \underline{\text { Robert Tinch }}^{7}, \underline{\text { Max Troell }}^{8}, \underline{\text { Peter Woodbury }}^{9}$, and Scot Zens ${ }^{10}$

${ }^{1}$ National Center for Ecological Analysis and Synthesis (NCEAS); ${ }^{2}$ CSIRO Entomology; ${ }^{3}$ Department of Systems Ecology, University of Stockholm; ${ }^{4}$ Rensselaer Polytechnic Institute; ${ }^{5}$ Conservation Ecology; ${ }^{6}$ University of British Columbia; ${ }^{7}$ School of Environmental Sciences, University of East Anglia; ${ }^{8}$ Beijer Institute, Royal Swedish Academy of Sciences; ${ }^{9}$ Boyce Thompson Institute for Plant Research; ${ }^{10}$ Department of Biology, Dartmouth College

- $\underline{\text { Abstract }}$

- Introduction

- Biotechnology and Agriculture

- Assessing the Risks and Benefits of Genetically Modified Crops

- Comparison to introduced species

- Scale and type of impacts

- Weighing risks and benefits

- $\underline{\text { Regulating risks }}$ 
- Reforming agriculture

- Public Dialogue and Science

- Conclusions

- Responses to this Article

- Literature Cited

\begin{abstract}
The benefits and risks of any particular GM crop depend on the interactions of its ecological functions and natural history with the agroecosystem and ecosystems within which it is embedded. These evolutionary and ecological factors must be considered when assessing GM crops. We argue that the assessment of GM crops should be broadened to include alternative agricultural practices, ecosystem management, and agricultural policy. Such an assessment would be facilitated by a clearer understanding of the indirect costs of agriculture and the ecological services that support it. The benefits of GM crops should be compared to those of other means of agricultural intensification such as organic farming, integrated pest management, and agricultural policy reform. A gradual and cautious approach to the use of GM crops that relies on a truly comprehensive risk assessment could allow people to reap substantial benefits from GM crops while mitigating their serious risks.
\end{abstract}

KEY WORDS: agriculture, biotechnology, genetically modified crops (GM), interdisciplinary, public dialogue, regulation, risk assessment.

Published: March 27, 2000

\title{
INTRODUCTION
}

Worldwide, the area planted in genetically modified (GM) crops has increased dramatically in recent years. Between 1996 and 1999, it rose from 1.6 X $10^{6}$ ha to more than 35 X $10^{6}$ ha (James 1998, May 1999). This rapid increase has provoked an explosion of concern, particularly in Europe, over the health and environmental impacts of these crops. Despite claims of safety and warnings against popular panic, public concern over GM crops has resulted in changes in their marketing, labeling, planting, and trade. These changes have fueled an increasingly heated debate among environmental advocates, critics of industrial agriculture, seed companies, governments, and scientists. This debate has been characterized by exaggerations of both the safety and danger of GM crops, and by attempts to suppress and avoid public discussion.

This paper is the product of a discussion among an international, interdisciplinary group of scientists. Our discussion was based on the Forum articles in this issue of Conservation Ecology. These articles 
summarize the nature of the debate over biotechnology, describe ways to cope with potential ecological impacts of GM crops, provide insights into the cause and validity of public concern, and make suggestions on where to go from here. Our own dialogue, which was informed by these and other articles, attempts to broaden the debate and develop strategies for coping with and directing the development of biotechnology. As an interdisciplinary group, we do not try to assess the details of particular GM crops, but rather to connect the ecological, economic, and political issues that surround them.

As noted by Conway (2000), Pimentel (2000), and others, the balance of evidence suggests that GM organisms have the potential to both degrade and improve the functioning of agroecosystems. Depending on which GM crops are developed and how they are used, GM crops could lead to either increases or decreases in pesticide use, the enhancement or degradation of the ecological services provided by agroecosystems, or the loss or conservation of biodiversity. However, as Conway argues, the current character of GM crop development provides cause for concern.

\section{BIOTECHNOLOGY AND AGRICULTURE}

In his statement on crop biotechnology, Conway states "... Biotechnology is going to be an essential partner, if yield ceilings are to be raised, if crops are to be grown without excessive reliance on pesticides and herbicides, and if farmers on less favored lands are to be provided with crops that are resistant to drought and salinity, and that can make more efficient use of nitrogen and other nutrients." This argument is commonly used to advocate the development and use of GM crops, but it is not currently supported by either the consensus of scientists or any comprehensive comparison of agricultural alternatives.

Roughly 95\% of the world's farmers live in developing countries. Most of these people engage in smallscale, community-based agriculture. Over long periods of time, these communities have constructed complex systems of knowledge about their environment (Castillo and Toledo 2000). More recently, the "green revolution" succeeded in making food more easily available to most of the world's population. Increases in agricultural production were brought about by a combination of increased irrigation, more intensive use of fertilizers and plant protection chemicals, and the development of new crop varieties capable of responding to higher levels of inputs and management. However, this agricultural intensification often came at the expense of local ecosystems and human health. These changes reduced the ability of the poor to support themselves from local ecosystems while benefiting well-off farmers. The centralized nature of crop biotechnology will further this process by reducing local specificity and adaptation of agricultural practices, which increases both social dependency on external inputs to agriculture and decreases the ability of local agroecosystems to adapt to local environmental contexts (Gadgil 2000). While future biotechnology may be codeveloped in local communities, as Conway proposes, it currently is not. 
Furthermore, it is questionable whether technical innovation is what is needed to develop more productive agriculture. The area with the greatest current need for increased agricultural production is Africa, where the green revolution was largely a failure (Dyson 1999). It is unlikely that GM crops will eliminate the social problems that led to this failure. Conway acknowledges that a large body of social science research has demonstrated that famines are caused not by food shortages or a lack of agricultural technology, but by lack of access to food (Sen 1977, 1980). Food access is determined by institutional characteristics such as property rights, political stability, and social security systems. Even with stable or expanding food supplies, inequality in the area of food access can lead to starvation and malnutrition.

Genetically modified crops promise to increase the productivity of poor farmers in the developing world, but so do other agricultural technologies (Ruttan 1999, Thomas 1999). Rather than investing in GM crops, one could invest in organic farming, integrated pest management, water management, or crop breeding. A fair assessment of the relative merits of different agricultural practices requires a systematic understanding of these alternatives. However, there has been little systematic research on the relative ecological and economic merits of alternative agricultural systems. Agricultural research has tended to narrow its focus to single goals, such as reducing erosion or increasing crop yields, rather than regarding the management of agroecosystems as a component of regional ecosystem management.

\section{ASSESSING THE RISKS AND BENEFITS OF GENETICALLY MODIFIED CROPS}

Plant biotechnology offers many potential benefits to diverse groups of people. These benefits have led to the development of GM crops by private and public organizations. In response to public concern about these developments, governments around the world are creating regulations to manage the risks associated with the release of GM crops into agricultural systems. We discuss the regulation of plant introductions by comparing the introduction of GM crops to past experience with species introductions, before moving on to consider the specific properties of GM crop regulation.

Comparison to introduced species

The release of genetically modified organisms into the environment is frequently compared to the introduction of species into a novel environment. The introduction of some species, especially agricultural species such as maize, wheat, and chickens, has provided enormous benefits to people. However, the costs of species introductions have been huge and largely unexpected. In the United States, approximately 50,000 nonindigenous species cause environmental damage and losses estimated at U.S. \$137 billion per year (Pimentel et al. 2000). While many introduced species were not intentionally introduced, some agricultural species have escaped from cultivation. Again in the United States, 128 species of introduced crops have become serious weeds (Pimentel et al. 1989). It should be noted that there is relatively little public concern over the impacts of introduced species, which are known to be large, but substantial concern over the possible impacts of GM crops. 
Introduced species offer some lessons for GM crops. Once established, introduced species are almost impossible to remove from an ecosystem, because they are continually reproducing, dispersing, and evolving. Although ecologists continue to increase their understanding of the dynamics of introduced species, they rarely manage to keep these species from spreading.

Compared with introduced species, the immediate ecological impacts of GM crops are likely to be minimal. GM crops are usually more dependent on human support than are introduced species. For example, crops typically depend on the removal of potential competitors by pesticides and mechanical disturbance. Furthermore, GM species can be engineered to be sterile or contain traits such as a reduced ability to disperse. Such technology may even help control invasive species (Walker and Lonsdale 2000). However, as the area and diversity of GM organisms increase, the risk that GM crops or genes may escape also increases. If introduced GM organisms possess novel traits that increase their ability to survive outside managed systems, their potential ecological impact may, in fact, be much greater than that of a comparable introduced species (Regal 1993).

Scale and type of impacts

The risks associated with a GM crop depend on complex interactions among the specific genetic modification(s), the organism's natural history, and the properties of the ecosystem in which it is released. These complexities are compounded by the fact that the risks and benefits associated with a specific crop change and become more difficult to assess as the area planted increases.

As long as there are no unexpected interactions within the genome, the direct impact of specific genetic modifications of crops will probably be fairly predictable. Less direct impacts, such as the responses of surrounding ecosystems and people, are more difficult to predict. For example, the ultimate effect of a herbicide-resistant crop on agricultural practices is difficult to assess from field trials. Similarly, the complexity and cost of monitoring or conducting experiments increases with the size of the area in which the crops are being used. As Fig. 1 shows, it becomes more difficult to predict, test, and monitor the effects of GM crops as their scale increases and their impacts become less direct.

Fig. 1. The direct and indirect effects of genetically modified crops interact with the scale at which they are grown to determine the difficulty of predicting, testing, and monitoring their potential impacts.

GIF Image (9 K) 
We suggest that the use of a GM crop requires a comprehensive analysis that includes a weighting of potential benefits against risks. To date, crop scientists have focused on the effects of plants in agricultural systems, while environmentalists have focused on the social and ecological consequences of the widespread use of GM crops. Consequently, these two groups are often discussing different sets of risks and benefits. This mismatch probably contributes to the rancor of the current debate.

Weighing risks and benefits

Given the historical, political, and economic context of biotechnology, it is appropriate to question the completeness of current risk assessment practices. Aspects of GM crops that are relevant to the profits of farmers and agrobusiness have been well studied. However, the concerns of those who eat food, who live downstream, or who value biodiversity are only beginning to be addressed. Regulatory agencies have not been using ecologically comprehensible criteria to assess the risks associated with GM organisms (Parker and Kareiva 1996). This deficiency can be explained by the political pressure that has been exerted on agencies to rapidly approve the release of genetically engineered crops (Rissler and Mellon 1996). This pressure has left agencies without the physical, institutional, and conceptual framework necessary to thoroughly evaluate the risks associated with particular crops (Regal 1999).

One possible approach is to assess the risks and benefits of specific types of GM modification, for different species, in different ecological contexts. Some of the potential risks and benefits of specific GM crop modifications are shown in Table 1.

Table 1. Examples of the potential ecological benefits and risks of selected GM crops.

\begin{tabular}{|l|l|l|}
\hline \multicolumn{1}{|c|}{ GM modification } & \multicolumn{1}{c|}{ Benefits } & \multicolumn{1}{c|}{ Risks } \\
\hline $\begin{array}{l}\text { Herbicide resistance in } \\
\text { maize, cotton, other crops. }\end{array}$ & $\begin{array}{l}\text { Reduce herbicide use. } \\
\text { Increase opportunities } \\
\text { for reduced tillage } \\
\text { systems. }\end{array}$ & $\begin{array}{l}\text { Increase herbicide use. } \\
\text { Reduce in-field } \\
\text { biodiversity that may } \\
\text { reduce the ecological } \\
\text { services provided by } \\
\text { agricultural ecosystems. }\end{array}$ \\
\hline
\end{tabular}




\begin{tabular}{|c|c|c|}
\hline Maize with $B t$ toxin. & $\begin{array}{l}\text { Reduce pesticide use. } \\
\text { Kill fewer nontarget } \\
\text { organisms than } \\
\text { alternatives such as } \\
\text { broad-spectrum } \\
\text { pesticides. }\end{array}$ & $\begin{array}{l}\text { Promote development of } \\
B t \text { resistance, which will } \\
\text { eliminate } B t \text { as a relatively } \\
\text { safe pesticide. } \\
\text { Kill nontarget caterpillars } \\
\text { and butterflies, such as } \\
\text { monarchs (Pimentel 2000) }\end{array}$ \\
\hline $\begin{array}{l}\text { Virus resistance in small } \\
\text { grains due to coat proteins. }\end{array}$ & $\begin{array}{l}\text { Reduce insecticide use } \\
\text { to control insect } \\
\text { dispersers of } \\
\text { pathogens (Hails 2000). }\end{array}$ & $\begin{array}{l}\text { Facilitate the creation of } \\
\text { new viruses (Hails 2000). } \\
\text { Move genes into } \\
\text { nonagricultural } \\
\text { ecosystems where the } \\
\text { subsequent increase in } \\
\text { fitness of weedy species } \\
\text { could eliminate } \\
\text { endangered species. }\end{array}$ \\
\hline $\begin{array}{l}\text { Terminator or other sterilizing } \\
\text { traits in crops and } \\
\text { ornamentals. }\end{array}$ & $\begin{array}{l}\text { Prevent the movement } \\
\text { of traits to nontarget } \\
\text { species. } \\
\text { Prevent the movement } \\
\text { of introduced species } \\
\text { to other ecosystems } \\
\text { (Walker and Lonsdale } \\
\text { 2000). }\end{array}$ & $\begin{array}{l}\text { Prevent farmers from } \\
\text { developing their own seed } \\
\text { supplies adapted to local } \\
\text { conditions (Conway 2000). }\end{array}$ \\
\hline $\begin{array}{l}\text { Synthesis of vitamin A or } \\
\text { other nutrients. }\end{array}$ & $\begin{array}{l}\text { Improve nutrition of } \\
\text { people who depend } \\
\text { heavily on rice } \\
\text { (Conway 2000). }\end{array}$ & $\begin{array}{l}\text { Disrupt local ecosystems } \\
\text { if an ecologically limiting } \\
\text { nutrient or protein is } \\
\text { produced. }\end{array}$ \\
\hline $\begin{array}{l}\text { Nitrogen fixation by } \\
\text { nonlegumes. }\end{array}$ & $\begin{array}{l}\text { Reduce energy used in } \\
\text { fertilizer production } \\
\text { and application } \\
\text { (Pimentel 2000). }\end{array}$ & $\begin{array}{l}\text { Add to excess } \mathrm{N} \text { leaching } \\
\text { from agriculture, } \\
\text { degrading human health } \\
\text { and reducing biodiversity. }\end{array}$ \\
\hline
\end{tabular}

A list of risks and benefits provides a framework that makes it easier to screen for the possible combinations of technology, crop, and ecological context that are likely to be relatively benign or hazardous. However, constructing such lists is only the first step in a risk assessment. These risks need 
to be quantitatively assessed for specific organisms in different contexts on a case-by-case basis. Various groups of ecologists have developed a methodology for evaluating the use of GM crops (Tiedje et al. 1989, Scientists' Working Group on Biosafety 1998). They recommend an incremental, tiered approach to risk assessment that moves from the laboratory to greenhouse and field trials and finally to gradually increased, monitored use.

Table 2. Questions to assess the relative benefits and risks of a GM crop.

\begin{tabular}{|c|c|c|}
\hline Type of Impact & $\begin{array}{c}\text { Benefit-Related } \\
\text { Questions }\end{array}$ & $\begin{array}{c}\text { Risk-Related } \\
\text { Questions }\end{array}$ \\
\hline Agricultural & $\begin{array}{l}\text { Are alternatives available that } \\
\text { provide greater agronomic, } \\
\text { economic, social, and } \\
\text { ecological benefits? } \\
\text { Does the GM crop prevent } \\
\text { some specific harm to humans } \\
\text { or ecosystems, e.g., does it } \\
\text { reduce pesticide use? }\end{array}$ & $\begin{array}{l}\text { Are risks minimized though } \\
\text { good design, e.g., is it } \\
\text { certain that genes inserted } \\
\text { into chloroplast DNA cannot } \\
\text { escape through pollen? } \\
\text { Has the organism been } \\
\text { examined to determine } \\
\text { whether genetic } \\
\text { modifications to produce a } \\
\text { desired trait have not also } \\
\text { inadvertently produced risky } \\
\text { changes? }\end{array}$ \\
\hline Ecological & $\begin{array}{l}\text { Does the GM crop help solve } \\
\text { an existing environmental } \\
\text { problem, e.g., does it produce } \\
\text { sterile feral animals to control } \\
\text { pests (Walker and Lonsdale } \\
\text { 2000)? }\end{array}$ & $\begin{array}{l}\text { Does the modified trait have } \\
\text { the potential to increase the } \\
\text { fitness of the organism } \\
\text { outside of the managed } \\
\text { environment, e.g., does it } \\
\text { impart herbivore resistance } \\
\text { or increase the reproductive } \\
\text { rate? } \\
\text { In the locale of release, can } \\
\text { the trait spread to other } \\
\text { species, i.e., can the species } \\
\text { hybridize with other species } \\
\text { nearby? }\end{array}$ \\
\hline
\end{tabular}




\begin{tabular}{|c|c|c|}
\hline Social & $\begin{array}{l}\text { Will the benefits of this GM } \\
\text { organism be widely shared? } \\
\text { Does the GM crop provide } \\
\text { some specific benefit to } \\
\text { humans or ecosystems, e.g., } \\
\text { does it enhance human } \\
\text { nutrition or help restore } \\
\text { degraded land? }\end{array}$ & $\begin{array}{l}\text { Is a mechanism in place for } \\
\text { surveying for possible } \\
\text { negative effects after } \\
\text { widespread release has } \\
\text { occurred? } \\
\text { Who and what are at risk of } \\
\text { being negatively affected by } \\
\text { this GM crop? } \\
\text { Do institutions exist that } \\
\text { could mitigate the potential } \\
\text { impacts of GM crops? }\end{array}$ \\
\hline
\end{tabular}

While field trials are a necessary step in evaluating GM crops, on their own they are insufficient. A more comprehensive analysis is required that includes an assessment of the relative benefits and risks of GM crops for other ecosystems and for people. To illustrate this approach, we provide a partial list of the questions that such an assessment should include in Table 2. Comprehensive risk assessment could allow people to reap substantial benefits from GM crops while avoiding or mitigating serious risks.

Regulating risks

The regulatory systems designed to deal with GM crops should try to reduce the amount of risk and create the social adaptive capacity necessary to cope with the risks associated with new technologies. There are many different ways to achieve these goals. We briefly discuss three separate and complementary methods for addressing each of these challenges: biosafety protocols, a moratorium, and insurance.

Conway (2000) sensibly calls for adequate biosafety protocols in all countries. A step toward this goal was taken earlier this year when a number of countries agreed on the need for an international biosafety protocol for trade in GM organisms. However, the research and administration necessary to maintain this protocol will be expensive and must be further developed. Those who wish to produce GM crops should support the development and maintenance of a biosafety infrastructure, particularly in developing countries where it is most needed. Such support could be generated through taxes on GM crops, regulatory fees, or other mechanisms, such as a global biosafety process.

One of the current concerns is that GM crops will be widely planted before effective risk assessment procedures are in place. This has led to calls for a moratorium on the further approval of GM crops. 
Currently, Austria, the UK, and Germany have moratoriums, while the EU has a de facto moratorium. Such moratoriums delay the introduction of crops that could reduce the amount of ecological degradation produced by agriculture. However, moratoriums offer a number of benefits. A delay could provide the opportunity to develop institutions to effectively evaluate and monitor GM crops. It would also allow science to better assess the potential indirect impacts of existing GM crops, such as the evolution of $B t$ resistance. Furthermore, a moratorium may provide the time needed to allow a richer public debate to address how to fairly balance the risks and benefits of GM crops.

Given the uncertainty surrounding both the likelihood and degree of potential impacts of GM crops, it is sensible for society to purchase insurance against these risks (Costanza et al. 2000). However, due to the unknown and variable nature of risks, private insurance is virtually impossible, which forces the public to play this role. Taxes on the use of GM crops could function as a type of social insurance, as long as such a tax was invested in ecological conservation and restoration, to mitigate against any disruption caused by GM crops. Insurance mechanisms should be in place before GM crops are more widely used. In addition, it would be sensible for society to invest in developing mechanisms such as research, monitoring systems, and avenues for citizen involvement to provide an early warning of any negative impacts of GM crops.

Reforming agriculture

Reforming the scientific assessment and implementation of GM crops would be a great advance, but it will do little to solve most of the ecological problems associated with agriculture. That would require the reform of the political and economic institutions that affect agriculture.

Agricultural intensification does not necessarily have to be at the expense of ecological services. In fact, humanity can no longer afford this, because the impacts of agriculture on Earth's ecosystems are already massive (Daily 1999). However, it will be difficult to achieve productive, sustainable agriculture if society does not value ecological services. An assessment of the risks and benefits of GM crops would be greatly facilitated by efforts to value environmental services (e.g., considering the public costs of cleaning water following pesticide and fertilizer use). If these services are treated as an open-access resource, there is little incentive to conserve them. Appropriate institutions should be developed to manage the enhancement and continual provision of these services (Ostrom 1990, Costanza et al. 2000).

The economic value of ecological services is significant (Costanza et al. 1997). A recent economic study of UK agriculture estimates that the indirect costs of agriculture, which are those paid by the nonfarming members of society, are almost as large as agriculture's net income (Pearce 1999). The presence of large costs that are not paid for by agriculture suggests that total societal benefits could be increased by moving to a form of agriculture that is less intensive and requires fewer inputs. 


\section{PUBLIC DIALOGUE AND SCIENCE}

We join the other commentators (Ellstrand 2000, Gadgil 2000, Krebs 2000, Pimentel 2000, Walker and Londsdale 2000) in embracing Conway's call for a "new way of talking and reaching decisions" about development and the environment that is based upon "honesty, full disclosure, and a very uncertain shared future." However, we are concerned by his statement that the purpose of this dialogue is "to put science back at the center of a discussion of risks and benefits." Science is a necessary part of the debate over GM crops. However, a debate centered on science rather than on ethical, social, and political concerns will likely encourage further polarization and public distrust of science, which, as Krebs suggests, is a consequence of scientists' role to date in the UK debate over GM crops.

Public perceptions of safety are important aspects of social welfare. The existence of widespread public concern is an indicator of the failure of the existing system. Public concern over GM crops should not be ascribed simply to ignorance. As Krebs notes, the public acceptance of GM crops appears to decrease with scientific understanding. Skepticism over claims by regulatory agencies, corporations, and scientists that a new technology is safe is not surprising due to the many occasions when similar assurances have been proven wrong (Economic and Social Research Council 1999). May (1999) even suggests that concerns over GM crops in the UK can be classified into three types based on past failures: health concerns of the type associated with Bovine Spongiform Encephalopathy (BSE); ecological concerns about the transmission of unintended effects along the food chain, of which DDT provides a prime example; and concerns of the Hedgerow type about the ecological impacts of changing agricultural practices.

Risk assessment and risk management are political processes. It is difficult to determine what level of risk is acceptable for a given potential benefit, because, while the direct benefits tend to accrue to a small group of people, the risks of GM crop technology are widely distributed over the population at large. This type of asymmetry between groups is usually difficult to resolve without establishing new public institutions, because it is extremely hard to mobilize large groups of people who have experienced relatively minor losses, even when the total amount of those losses is substantial (Hardin 1982, Ostrom 1990). This asymmetry further highlights the prominent roles of politics and ethics in the debate over GM crops.

Science can be used to address these concerns and questions, but it will not resolve them. Those who fund research largely determine the questions to which science is applied. Technological development is usually funded by specific interest groups, and technology is used, at least initially, for the purposes and in the ways those groups intend. GM crops have been largely developed by agrobusiness companies that seek to maximize their return on investment. These companies are part of a global market system that encourages technological and resource-intensive solutions to problems. It is not surprising that the GM crops being developed share the ecological problems of other industrial inputintensive approaches to agricultural technology. Companies have a strong incentive to conduct research and develop crops that will increase their profits, hence the focus on products that require pesticides, fertilizers, and seeds. Current research on GM organisms is dominated by the goal of producing herbicide-resistant crops (Pimentel et al. 2000). Publicly funded agricultural research should be 
broadened to address questions such as: How can agroecosystems be designed to improve the quality of ecological services, decrease the loss of biodiversity due to agriculture, and increase sustainability?

The new dialogue that Conway calls for should broaden the discussion of GM crops to include their political, social, and ecological contexts while searching for answers to the fundamental questions of how to maintain ecological functions, move towards sustainable agriculture, and improve people's quality of life. Science can facilitate and usefully constrain this dialogue, but the primary constraints on the development of such a dialogue will be social rather than scientific.

\section{CONCLUSIONS}

This paper is the product of an international dialogue among individuals who are all more or less pessimistic about the the ability of technology, institutions, and society to effectively manage biotechnology. From our private dialogue, we achieved a new understanding of the interconnected issues in which the debate over GM crops is embedded, and we hope that a broader, more in-depth version of this process will improve the ways in which biotechnology is used and not used.

We concluded that the specific impacts of any particular GM crop depend on the interactions of its ecological function and natural history with the agroecosystem and ecosystems within which it is embedded. The benefits of some GM crops in some agricultural systems appear to outweigh their relatively low risks, but others are substantially more risky. While biotechnology could be used to produce large social and ecological benefits, most GM crops developed to date have been designed to benefit agrobusiness while exposing people and ecosystems to substantial risks. Due to this pattern, there is widespread suspicion of agricultural biotechnology and its advocates.

Discussions of GM crops should be broadened to include alternative agricultural practices, ecosystem management, and agricultural policy. Such a discussion would be facilitated by a clearer understanding of the indirect costs of agriculture and the indirect subsidies it receives from nature. Furthermore, this discussion should test the proposition that GM crops are the best means of agricultural intensification compared with other agricultural technologies. A gradual and cautious approach to the use of GM crops that relies on a truly comprehensive risk assessment could allow people to reap substantial benefits from GM crops while mitigating their serious risks.

\section{RESPONSES TO THIS ARTICLE}

Responses to this article are invited. If accepted for publication, your response will be hyperlinked to the article. To submit a comment, follow this link. To read comments already accepted, follow this link. 


\section{LITERATURE CITED}

Castillo, A., and V. M. Toledo. 2000. Applying ecology in the Third World: the case of Mexico. BioScience 50: 66-76.

Conway, G. 2000. Genetically modified crops: risks and promise. Conservation Ecology 4(1): 2. [online] URL: http://www.consecol.org/vol4/iss1/art2

Costanza, R., H. Daly, C. Folke, P. Hawken, C. S. Holling, A. J. McMichael, D. Pimentel, and D. Rapport. 2000. Managing our environmental portfolio. Bioscience 50: 149-155.

Costanza, R., R. d'Arge, R. de Groot, S. Farber, M. Grasso, B. Hannon, K. Limburg, S. Naeem, R. V. O'Neill, J. Paruelo, R. G. Raskin, P. Sutton, and M. van den Belt. 1997. The value of the world's ecosystem services and natural capital. BioScience 387: 253-260.

Daily, G. C. 1999. Developing a scientific basis for managing Earth's life support systems. Conservation Ecology 3(2): 14. [online] URL: http://www.consecol.org/vol3/iss2/art14

Dyson, T. 1999. World food trends and prospects to 2025. Proceedings of the National Academy of Sciences (USA) 96(11): 5929-5936.

Economic and Social Research Council (ESRC), Global Environmental Change Programme. 1999. The politics of GM food: risk, science and public trust. Special Briefing Number 5. University of Sussex, Falmer, UK. [online] URL: http://www.gecko.ac.uk/gm-briefing.html

Ellstrand, N. 2000. The elephant that is biotechnology: Comments on "Genetically modified crops: risks and promise" by Gordon Conway. Conservation Ecology 4(1):8. [online] URL: http://www. consecol.org/vol4/iss1/art8

Gadgil, M. 2000. Comments on "Genetically modified crops: risks and promise" by Gordon Conway. Conservation Ecology 4(1): 9. [online] URL: http://www.consecol.org/vol4/iss1/art9

Hails, R. S. 2000. Genetically modified plants - the debate continues. Trends in Evolution and Ecology 15(1): $14-18$.

Hardin, R. 1982. Collective action. Johns Hopkins University Press, Baltimore, Maryland, USA.

James, C. 1998. Global review of commercialized genetically modified crops. ISAAA Brief Number 8. International Service for the Acquisition of Agri-biotech Applications, Ithaca, New York, USA. 
Krebs, J. R. 2000. GM foods in the UK between 1996 and 1999: Comments on "Genetically modified crops: risks and promise" by Gordon Conway. Conservation Ecology 4(1): 11. [online] URL: http:// www.consecol.org/vol4/iss1/art11

Matson, P. F., W. J. Parton, and M. J. Swift. 1997. Agricultural intensification and ecosystem properties. Science 277: 504-508.

May, R. M. 1999. Genetically modified foods: facts, worries, policies and public confidence. Office of Science and Technology, London, UK. [online] URL: http://www.dti.gov.uk/ost/genetic/geni.htm

Ostrom, E. 1990. Governing the commons: the evolution of institutions for collective action. Cambridge University Press, New York, New York, USA.

Parker, I. M., and P. Kareiva. 1996. Assessing the risks of invasion for genetically engineered plants: acceptable evidence and reasonable doubt. Biological Conservation 78: 193-203.

Pearce, F. 1999. Crops without profit. New Scientist 164(2217). [online] URL: http://www. newscientist.com/19991218/newsstory4.html

Pimentel, D., M. S. Hunter, J. A. Lagro, R. A. Efroymson, J. C. Landers, F. T. Mervis, C. A. McCarthy, and A. E. Boyd. 1989. Benefits and risks of genetic engineering in agriculture. BioScience 39(9): 606-614.

Pimentel, D. 2000. Genetically modified crops and the agroecosystem: Comments on "Genetically modified crops: risks and promise" by Gordon Conway. Conservation Ecology 4(1): 10 [online] URL: http://www.consecol.org/vol4/iss1/art10

Pimentel, D., L. Lach, R. Zuniga, and D. Morrison. 2000. Environmental and economic costs of nonindigenous species in the United States. BioScience 50(1): 53-64.

Regal, P. J. 1993. The true meaning of exotic species as a model for genetically engineered organisms. Experientia 49(3): 225-234.

Regal, P. 1999. A brief history of biotechnology risk debates and policies in the United States. Occasional paper. Edmonds Institute, Edmonds, Washington, USA. [online] URL: http://www. edmonds-institute.org/regal.html

Rissler, J., and M. Mellon. 1996. The ecological risks of engineered crops. MIT Press, Cambridge, Massachusetts, USA. 
Ruttan, V. W. 1999. The transition to agricultural sustainability. Proceedings of the National Academy of Sciences (USA) 96(11): 5960-5967

Scientists' Working Group on Biosafety. 1998. Manual for assessing ecological and human health effects of genetically engineered organisms. Edmonds Institute, Edmonds, Washington, USA. [online] URL: http://www.edmonds-institute.org/manual.html

Sen, A. K. 1977. Starvation and exchange entitlements: a general approach and its application to the Great Bengal Famine. Cambridge Journal of Economics 1(1): 33-59.

Sen, A. K. 1980. Poverty and famines: an essay on entitlements and deprivation. Clarendon Press, Oxford, UK.

Thomas, M. B. 1999. Ecological approaches and the development of "truly integrated" pest management. Proceedings of the National Academy of Sciences (USA) 96(11): 5995-6000.

Tiedje, J. M., R. K. Colwell, Y. L. Grossman, R. E. Hodson, R. E. Lenski, R. N. Mack, and P. J. Regal. 1989. The planned introduction of genetically engineerged organisms: ecological considerations and recommendations. Ecology 70(2): 298-315.

Walker, B., and M. Lonsdale. 2000. Genetically modified organisms at the crossroads: Comments on "Genetically modified crops: risks and promise" by Gordon Conway. Conservation Ecology 4(1): 12. [online] URL: http://www.consecol.org/vol4/iss1/art12

\section{Address of Correspondent:}

Garry Peterson

National Center for Ecological Analysis and Synthesis (NCEAS)

735 State St, Suite 300,

Santa Barbara, California 93101-5504 USA

Phone: 805 892-2528

peterson@nceas.ucsb.edu

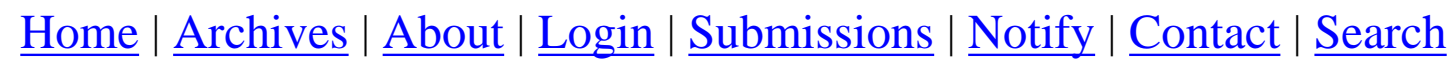

